\title{
Intybia (Protolaius), a new subgenus of soft winged flower beetles (Coleoptera: Malachiidae) from Indonesia
}

\section{Intybia (Protolaius) - новый подрод жкуков махашек (Coleoptera: Malachiidae) из Индонезии}

\author{
S.E. Tshernyshev \\ С.Э. Чернышёв
}

\author{
Institute of Animal Systematics and Ecology, Russian Academy of Sciences, Siberian Branch, Frunze Street 11, Novosibirsk 630091, \\ Russia. E-mail: sch-sch@mail.ru \\ Tomsk State University, Lenina prospekt 36, Tomsk 634050, Russia. \\ Институт систематики и экологии животных СО РАН, ул. Фрунзе 11, Новосибирск 630091, Россия. \\ Томский государственный университет, проспект Ленина 36, Томск 630050, Россия.
}

KEY WORDS: Coleoptera, Malachiidae, Intybia, Protolaius, Sumatra, Lombok, new subgenus, soft winged flower beetle.

КЛЮЧЕВЫЕ СЛОВА: Coleoptera, Malachiidae, Intybia, Protolaius, Суматра, Ломбок, новый подрод, жуки малашки.

ABSTRACT. A new subgenus, Intybia (Protolaius) subgen.n., is described in the tribe Apalochrini (Coleoptera: Malachiidae, Malachiinae) on the basis of the male special structures of Intybia schillhammeri (Wittmer, 1996), which is known from Sumatra, Indonesia. The slender body with modified 1st and 3rd antennal segments in the male allow one to attribute this species to the genus Intybia Pascoe, but the emarginations on the outer sides of the anterior femora in the male and dark-blue metallic colouration of the upperside which are similar to the genus Laius Guérin-Méneville, 1831 have previously not been known in Intybia representatives. Thus, the male of Intybia schillhammeri demonstrates the evolutionary similarity between these two genera and presumably could be considered as a transitive form between them. A detail description and illustrations of male special characters of a type species and a diagnosis of the new subgenus are provided. The species that have been previously described from Sumatra in the genus Intybia are also discussed.

РЕЗЮМЕ. На основании исследования специфических структур самца Laius schillhammeri Wittmer, 1996 с острова Суматра в Индонезии, передние голени и бёдра которого не вздуты и не модифицированы в виде сложно скульптурированного органа, а переднеспинка не простая узкая поперечная, как у представителей рода Laius GuérinMéneville, 1831, вид ранее был перенесен в род Intybia Pascoe 1866 - I. schillhammeri (Wittmer,
1996) [Plonski, 2013]. Несмотря на то, что ряд таких признаков, как: стройное узкое тело, простые передние ноги, модифицированные 1 и 3 членики усиков позволяют отнести вид к роду Intybia Pascoe, тем не менее, вырезанные передние бёдра самца с пучком волосков, а также тёмно-синяя металлическая окраска покровов сближают данный вид с родом Laius Guérin-Méneville, 1831. Таким образом, самец I. schillhammeri демонстрирует эволюционную близость между двумя упомянутыми выше родами и, вероятно, может рассматриваться как переходная форма между ними. В связи с этим, описан новый подрод жуков малашек Intybia (Protolaius) subgen.n. в трибе Apalochrini (Coleoptera: Malachiidae, Malachiinae). Представлены детальное описание и фотографии внешнего вида и специфических структур самца типового вида с диагнозом нового подрода. Обсуждаются виды, ранее описанные с Суматры в роде Intybia, и их современное таксономическое положение.

\section{Introduction}

The genus Intybia Pascoe, 1865 belongs to the tribe Apalochrini and includes representatives with a characteristic small second segment of the antennae almost completely hidden by a scapus. The txonomic structure of the tribe has been recently discussed with special reference to South-Asian genera [Plonski, 2013, 2014a,

How to cite this article: Tshernyshev S.E. 2020. Intybia (Protolaius), a new subgenus of soft winged flower beetles (Coleoptera: Malachiidae) from Indonesia // Russian Entomol. J. Vol.29. No.2. P.173-177. doi: 10.15298/ rusentj.29.2.08 
b, 2016, 2017; Plonski, Geiser, 2014; Tshernyshev, 2015], and three genera, Troglointybia Tshernyshev, 2015, Mimapalochrus Tshernyshev, 2015 and Oculapalochrus Tshernyshev, 2015 were described. Later, a genus Pectapalochrus Tshernyshev, 2016, endemic to inner the Eurasian steppes was also described [Tshernyshev, 2016b]. Obviously, the tribe Aplochrini, is taxonomically rich in southern areas and worthy of further study.

Amongst those genera currently known in the tribe, four generic groups should be considered, namely: Apalochrus-group (Apalochrus Erichson, 1840, Paratinoides L. Medvedev, 1964, Protapalochrus Evers, 1987, Pectapalochrus Tshernyshev, Oculapalochrus Tshernyshev etc.), Collops-group (Collops Erichson, 1840, Protocollops Evers, 1991, Troglocollops Wittmer, 1965, Simoderus Abeille de Perrin, 1891), Laius-group (Laius Guérin-Méneville, 1838, Intybia, Troglointybia Tshernyshev, Dicranolaius Champion, 1921, Eulaius Wittmer, 1996 etc.), and Dromanthomorphus-group (Dromanthomorphus Pic, 1921, Hadrocnemus Kraatz, 1895, Mimapalochrus Tshernyshev etc.). The Laius-group is one of the most common in SE Asia and Indonesia occurring in coastal zone, sometimes on stones washed with seawaters. That is why three specimens of Intybia Pasco laying on cotton wool together with other beetles collected in Sumatra by Alexei Moseyko, Saint-Petersburg attracted attention. One specimen is a female with black elytra spotted with yellow-white making maculae, and another two are completely blue-metallic male and female with a poorly visible sexual dimorphism. The first species is provisionally identified as Laius luteonotatus Pic, 1921, on the basis of the typical colouration of the upperside, but for species attribution male special charters (mainly antennae and genitalia) should be also studied. The second species is L. shilhammeri Wittmer, 1996, endemic to the Sumatran fauna. The external appearance of this beetles is typical of Intybia, due to the slightly elongate and slender body, and the male antennal segment 3 is enlarged and modified. The completely dark blue colouration would make one to believe it to be a representative of Stenolaius Wittmer, 1995 or perhaps a narrow bodied Laius. The simple head and lack of a tarsal comb in the anterior leg of the male questions its attribution to Stenolaius, and the simple fore-tibiae in the male and the narrow, coarsely punctured body would not place this species to Laius. The only genus appropriate for L. shilhammeri is Intybia, but one male character, namely the excavate fore femora, differs this species from all known representatives of the genus proposed.

The genus Intybia was recently revised [Tshernyshev, 2016a], the type species being re-treated, redescribed and illustrated. The nominative species, $I$. guttata Pascoe, 1866, was described from a small Island of Indonesia on the basis of the female only. Naturally, the lack of special male characters in type species complicates a proper definition of the genus Intybia, but a comparative analysis of these structures in the conge- ners widely distributed in Indonesia allows one to consider Intybia male characters as follows: Anterior tarsi 5-segmented, simple, lacking comb, legs simple, without emarginations or modifications, head smooth lacking sculpture, $1^{\text {st }}$ and $3^{\text {rd }}$ (or only $3^{\text {rd }}$ ) antennomeres enlarged and modified. Colouration of Intybia species range from monochromous black or dark grey to different combinations of rufous, red, yellow or white with a metallic lustre to dark parts. Puncturation and pubescence of the upperside of Intybia also vary from smooth to coarse punctures and from a dense pubescence to areas with sparse short and thin hairs. The genus Intybia is rich in species that include forms that look like representatives of other genera that only further taxonomy will resolve.

The genus Laius, in contrast to Intybia, differs possessing a similar external appearance amongst its congeners; namely wide and flattened beetles with a narrow transversal pronotum with evenly rounded sides, a finely punctured and pubescent upperside always dark blue with a metallic lustre. The $1^{\text {st }}$ and $3^{\text {rd }}$ antennomeres in the male are enlarged and modified as in Intybia, but the characteristic anterior legs of the male with enlarged and excavate femora and tibiae, sometimes curved inwards, differentiate this genus from other representatives of the tribe Apalochrini.

Laius shilhammeri cannot be considered as Laius because of different body shape, elongate and slender, narrowed downwards pronotum, coarsely punctured surface and simple anterior legs of male. Thus, the species could be considered as a species of Intybia or Troglointybia genera, but the simple head lacking traces of sculpture places this species in Intybia. However, the only problem impeding attribution of the species to the latter genus is the specific character in the anterior femora, i.e. an excavation possessing narrow tuft of hairs. This shape is unknown in other members of the Laius-group. Taking into account the wide and various morphological status of Intybia representatives, the only way to fix this new character taxonomically is propose a new subgenus, Protolaius subgen.n., which is described below.

Initially, eight species of Laius were described and since they are known only from Sumatra, they can be regarded as endemics. Later, three species, L. corporaali $\mathrm{Pic}, 1921$, L. diabolicus $\mathrm{Pic}, 1905$ and L. pisanganus Pic, 1921 were attributed to the new genus Stenolaius, and two species were transferred in two different genera, L. adonis (Pic, 1921) to Dicranolaius and $L$. sumatrensis Wittmer, 1954 and L. luteonotatus Pic, 1921 to Intybia [Plonski, 2016]. After the present revision of I. schillhammeri (Wittmer, 1996), a species, $L$. albodiversus Pic, 1929, remains in the genus Laius. Taking into account the monochromous blue metallic colouration of Laius and the black of Stenolaius, attribution of the latter species could be considered for either Dicranolaius or Intybia and therefore is questionable and need of revision.

Beetles were studied using an Amscope trinocular 
stereomicroscope (Ultimate Trinocular Zoom Microscope 6.7X-90X Model ZM-2TY), and digital photographs were taken using a Carl Zeiss Stemi 2000 trinocular microscope and the AxioVision programme. Male genitalia, embedded in DMHF (Dimethyl hydantoin formaldehyde), were mounted onto a transparent card and pinned under the specimen. Specimens have been deposited at the collection of Zoological Institute of the Russian Academy of Sciences, Saint-Petersburg (ZISP).

\section{Intybia (Protolaius) Tshernyshev, subgen.n.}

Type species: Laius schillhammeri Wittmer, 1996, designated herewith.

DESCRIPTION. Moderately small-size (c. $3.5 \mathrm{~mm}$ ) malachiid beetles with slightly elongate sub-oval body, slightly expanded posteriorly (Figs 1-3). Upperside with monochromous colouration of dark-blue metallic lustre, roughly and sparsely puncturation and sparse long dark and erect pubescence of head, pronotum and elytra are typical for the subgenus. Antennae (Fig. 4) filiform, not serrate, thin, almost completely reaching middle of elytra; in male $1^{\text {st }}$ and $3^{\text {rd }}$ segments enlarged, scapus clavate, sub-triangularly widened distally, the $3^{\text {rd }}$ segment oval, slightly flattened, complicatedly impressed, lacking a tuft of hairs. Palpae short, apical segment sub-oval and truncate. Head conjugate with convex anterior part of the pronotum, slightly wider than pronotum, eyes small, round, protruding, disc of the head between eyes slightly depressed. Pronotum transverse, weakly protruding and convex anteriorly, strongly depressed and sinuate to the base just behind the middle, with posterior margin elevate and swollen; sides with thin margins, anterior angle rounded, posterior distinct and almost at a complete right angle.

Elytra sub-oval and elongate (Figs 1-3), slightly expanded posteriorly, coarsely punctured, with short and slightly protruding shoulders; apices evenly rounded, simple. Surface evenly covered with strong, erect sparse black hairs and sparse short light-coloured adpressed pubescence on periphery. Anterior femora in male excavate in the middle and provided with a tuft of light-coloured long straight hairs (Figs 6-7), anterior tarsi simple, lacking comb (Fig. 5). Metathorax slightly swollen, transverse, simple, lacking appendages or tufts of hairs. Apical tergite in male undivided, simple, transversal, narrow, apical sternite bilaciniate, narrow, transverse, aedeagus slightly curved, extremely elongate at apical third, with evenly narrowed and short lamella, two strong long horns in inner sac are noticeable at base of the aedeagus (Figs 8-11).

DIAGNOSIS. Monochromous dark blue metallic coloured beetles of c. $4 \mathrm{~mm}$ in length, roughly punctured and densely covered with strong erect black setae. Pronotum strongly sinuate at base and narrower than elytra. Sexual dimorphism is not contrasting, noticeable in $1^{\text {st }}$ and $3^{\text {rd }}$ antennomeres and excavate femora in males. From representatives of the nominative subgenus it can be easily separated by the male characters, namely excavate femora and aedeagus with extremely elongate apical part.

ETYMOLOGY. The name of the subgenus reflects similarity with the genus Laius according to the special male character of the anterior femora that can be considered to be an ancestral character of the genus.

NOTES. Two species are included in the subgenus due to typical male femora in anterior legs, I. (P.) schillhammeri and I. (P.) lombokana (Pic, 1910) (= I. jaechi (Wittmer, 1996)). The decision is based on study of types of these species, kindly carried out by Isidor S. Plonski. He informed that the photos was compared with the holotype of I. schillhammeri, and are found conspecific. The only difference is in colouration, the third antennomere in holotype is brownish enlightened on the inner side. Furthermore, the excavated femorae in I. schillhammeri and I. lombokana are confirmed. Presumably, Intybia cibrosa (Pic, 1937) could also be included in this subgenus, but the male special characters should be examined first in view of the poor original description of the species.

List of species in the subgenus Intybia (Protolaius):

I. (P.) schillhammeri (Wittmer, 1996) - Indonesia: Sumatra Island;

I. (P.) lombokana (Pic, 1910) (= I. jaechi (Wittmer, 19960) - Indonesia: Lombok Island.

\section{Intybia (Protolaius) schillhammeri}

(Wittmer, 1996), comb.n.

Figs 1-12.

Laius schillhammeri Wittmer, 1996: 319, 320, figs. 240, 241; Intybia schillhammeri (Wittmer, 1996): Plonski, 2013: 65; 2016: 31.

MATERIAL. INDONESIA, W Sumatra, Prov. Sungai Pinang, $18 \mathrm{~km}$ S Padang, $01^{\circ} 08^{\prime} 36^{\prime \prime} 100^{\circ} 24^{\prime} 48^{\prime \prime}$ E, 0-300 m a.s.1., 22.2.2017, A. Moseyko leg. $-10^{7}, 1$.

DESCRIPTION. Male (Figs 1, 2). Body elongate, suboval, slightly expanded just behind the middle.

Body black excepting impressed areas in $3^{\text {rd }}$ antennomere, apices of coxae and commissure sides of sternites light brown. Elytra, pronotum and head completely black with dark blue metallic lustre. Surface evenly covered with sparse long erect black hairs, head and pronotum additionally with a light-coloured fine adpressed pubescence. Vesicles brownyellow, thoracic mesepimera black.

Head somewhat wider than pronotum, eyes round, small, protruding over the sides of the head, disc of the head between eyes slightly impressed, simple, genae short and strongly impressed; clypeus transverse, narrow, straight and slightly elevate; labrum transverse; palpae short, apical segment sub-oval and truncate; surface of head dull, sparsely punctured and covered with light-coloured short adpressed and black semi-erect hairs.

Antennae filiform (Fig. 4), $2.0 \mathrm{~mm}$ long, almost completely reaching the middle of the elytra; $1^{\text {st }}$ segment enlarged, clavate-triangular, $2^{\text {nd }}$ segment small, round, the $3 \mathrm{rd}$ segment oval, slightly flattened, complicatedly impressed, lacking bunch of hairs; 4th and $5^{\text {th }}$ antennomeres equilateral, each of them double the length of the $2^{\text {nd }}$, remaining segments each slightly longer that the $5^{\text {th }}$, sub-cylindrical; 11 th segment somewhat longer than previous, evenly narrowed and pointed at apex; surface evenly covered with short black semierect pubescence.

Pronotum longitudinal, strongly narrowed from middle to base, anterior half convex and strongly impressed behind, posterior margin elevate and swollen; anterior part slightly convex, posterior straight, lateral and basal sides distinctly marginate; surface shiny, sparsely and finely punctured at the swollen part, and coarsely at the periphery, sparsely covered with fine light semi-erect pubescence and long erect black hairs.

Scutellum small, rectangular and transversal, narrow but distinct, sparsely punctured and covered with sparse dark fine pubescence.

Elytra sub-oval and sub-parallel, widened posteriorly just behind the middle, at base strongly wider than pronotum; humeri small, distinct, weakly protruding; apices evenly rounded, simple; surface shiny, coarsely punctured, with 
indistinct microsculpture, sparsely covered with long black erect hairs.

Hind wings normally developed.

Legs short and thin; posterior femora almost completely reaching apex of the elytra; all tibiae thin and straight, femora narrow, slightly compressed, not curved, anterior femora in male excavate in a middle and provided with a bunch of lightcoloured long straight hairs (Figs 6-7); all tarsi 5-segmented, narrow, 2nd segment in anterior tarsi simple, lacking comb (Fig. 5), claw-segment longest and somewhat wider in all

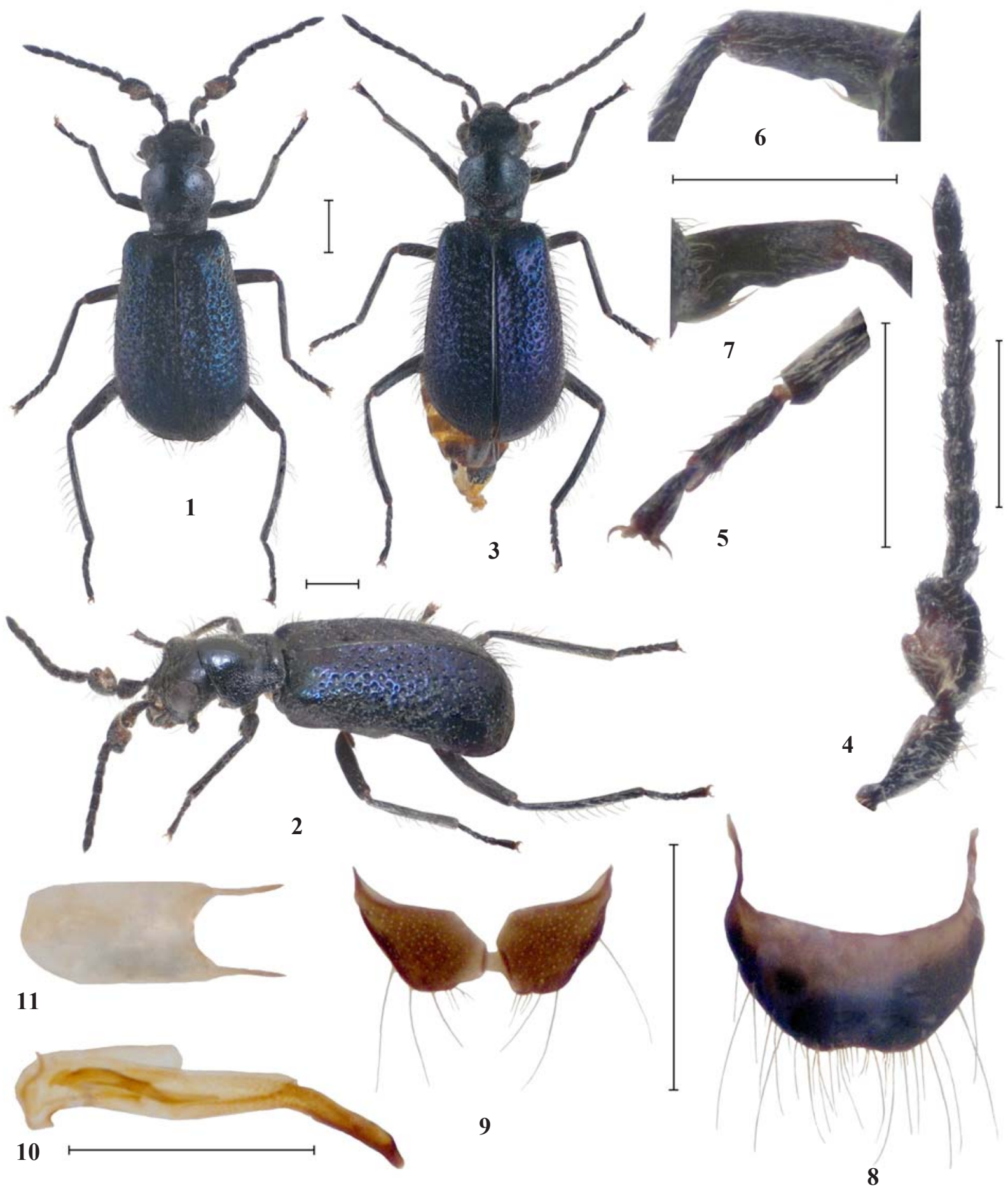

Figs 1-11. Intybia (Protolaius) schillhammeri (Wittmer, 1996), male (1-2, 4-11) and female (3). 1, 3 - external appearance, dorsal view; 2 - external appearance, lateral view; 4 - left antenna; 5 -right anterior tarsus; 6 - femur of left anterior leg; 7 - femur of right anterior leg; 8 - apical tergite; 9 - apical sternite; 10 - aedeagus, lateral view; 11 - tegmen. Scale bars: $0.5 \mathrm{~mm}$.

Рис. 1-12. Intybia (Protolaius) schillhammeri (Wittmer, 1996), самец (1-2, 4-11) и самка (3). 1-2 - внешний вид дорзально; 2 внешний вид, сбоку; 4 - левый усик; 5 - правая передняя лапка; 6 - бедро левой передней ноги; 7 - бедро правой передней ноги; 8 - апикальный тергит; 9 - апикальный стернит; 10 - эдеагус, латерально; 11 - тегумен. Масштаб: 0,5 мм. 
legs, it is dorsally flattened while remaining segments compressed, 1.1 times longer than $1 \mathrm{st}$ and $2^{\text {nd }}$ segments in anterior and intermediate tarsi, and 1.2 times longer than $1^{\text {st }}$ and $2^{\text {nd }}$ segments in posterior tarsi; claws sharp, thin, with round membrane at base.

Ventral body surface sparsely punctured, dull, sparsely covered with fine, depressed dark pubescence; metathorax slightly swollen, bituberculate, lacking appendage or hairs. Apical tergite transverse, evenly rounded and cut at apex (Fig. 8); apical sternite bilaciniate, transverse, cut at apex (Fig. 9); aedeagus slightly curved, extremely elongate at apical third, with evenly narrowed and short lamella, two strong long horns in inner sac are noticeable at base of the aedeagus (Fig. 10); tegmen elongate, with short thin and pointed parameres 3.5 times shorter than the base of tegmen (Fig. 11).

Length $3.5 \mathrm{~mm}$, width (at elytral base) $1.2 \mathrm{~mm}$.

Female. Differs from male by the somewhat elongate and slenderer antennae with the 3 rd antennomere rectangular, not impressed or sculptured, double the width of the 4th antennomere and almost the same length as the 1st. Length $3.5 \mathrm{~mm}$, width (at elytral base) $1.2 \mathrm{~mm}$ (Fig. 3).

HABITAT. Beetles were collected on vegetation in park at an altitude of c. $300 \mathrm{~m}$ above sea level. Further details of the bionomy of this species remain unknown.

DISTRIBUTION. Indonesia: Sumatra (Fig. 12).

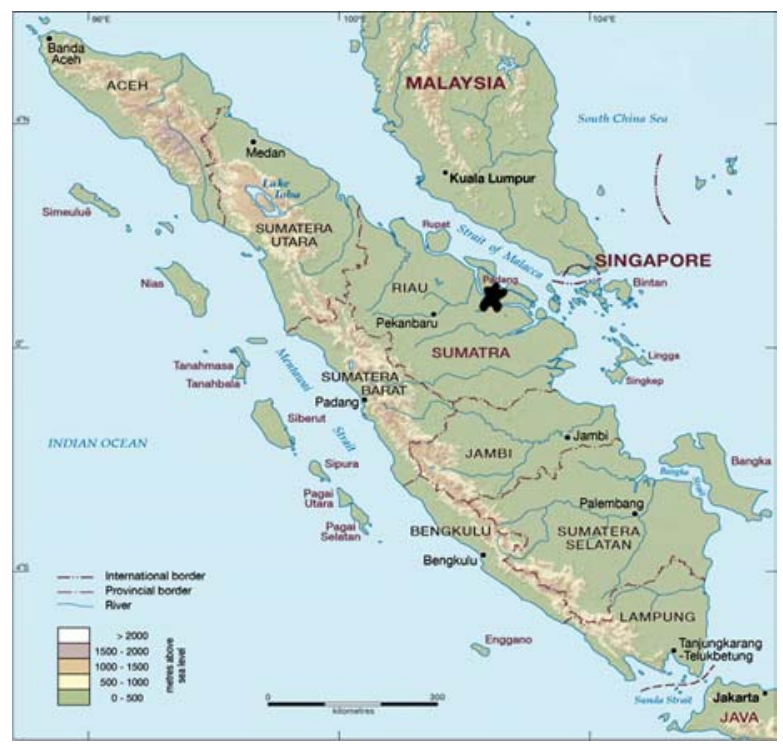

Fig. 12. Distribution map.

Рис. 12. Карта распространения.
Acknowledgements. The author is gratitude to A.G. Moseyko (Zoological Institute, Saint-Petersburg) for collecting the beetles in Sumatra and loaning them to me for this study, and to Prof. Mark Seaward (Bradford University, U.K.) for the linguistic revision of the text, and to Isidor Plonski (Vienna, Austria) for his kind help regarding copies of literature and discussion of Malachiidae taxonomy.

This study was supported by the Federal Fundamental Scientific Research Programme for 2013-2020, grant No. VI.51.1.5 (AAAA-A16-116121410121-7).

\section{References}

Plonski I.S. 2013. Studies on the genus Intybia Pascoe (Coleoptera: Malachiidae) I. Some nomenclatorial acts and faunistic records // Zeitschrift der Arbeitsgemeinschaft Österreichischer Entomologen. Bd.65. P.61-68.

Plonski I.S. 2014a. Studies on the genus Intybia PASCOE, part II. Faunistic and taxonomic notes, with description of a new species of the I. plagiata-group (Coleoptera: Malachiidae) // Koleopterologische Rundschau. Bd.84. P.313-320.

Plonski I.S. 2014b. Studies on the genus Intybia Pascoe (Coleoptera: Malachiidae) IV. Notes on the fauna of the Philippines // Zeitschrift der Arbeitsgemeinschaft Osterreichischer Entomologen. Bd.66. P.39-45.

Plonski I.S. 2016. Studies on the genus Intybia Pascoe (Coleoptera: Malachiidae) V. Contribution to internal classification and taxonomy, with faunistic and nomenclatorial notes // Zeitschrift der Arbeitsgemeinschaft Osterreichischer Entomologen. Bd.68. P.17-38.

Plonski I.S. 2017. Colotrema socotrana sp. nov. from Socotra Island, with new records of the genus from Yemen (Coleoptera: Malachiidae) // Acta Entomologica Musei Nationalis Pragae. T.57. Suppl. P.125-131. https://doi.org/10.1515/aemnp-2017-0113.

Plonski I.S., Geiser M.F. 2014. Studies on the genus Intybia Pascoe (Coleoptera: Malachiidae) III. On Intybia rubrithorax (Pic) and related taxa // Zeitschrift der Arbeitsgemeinschaft Osterreichischer Entomologen. Bd.66. P.31-38.

Tshernyshev S.E. 2015. Soft winged flower beetles (Coleoptera, Malachiidae) of the Himalaya region, with notes on Apalochrini // Biodiversität und Naturasstattung im Himalaya. Vol.5. P.389-405.

Tshernyshev S. E. 2016a. Pectapalochrus gen. nov., a new genus of soft-winged flower beetles of the tribe Apalochrini (Coleoptera, Malachiidae) // Zoologicheskii zhurnal. T.95. No.3. P.300-305. DOI: 10.7868/S0044513416030041 [in Russian, with English summary]

Tshernyshev S.E. 2016b. Taxonomic revision of Intybia Pascoe, 1886 species (Coleoptera, Malachiidae) of Thailand and Philippines // Zootaxa. Vol.4147. No.2. P.101-123. http://doi.org/ 10.11646/zootaxa.4147.2.1.

Wittmer W. 1996. Zur Kenntnis der Familie Malachiidae (Coleoptera). Teil II // Mitteilungen der Schweizerischen Entomologischen Gesellschaft (= Bulletin de la Société Entomologique Suisse). Bd.69. S.297-327. 